\title{
Література:
}

1. Дурович А. П. Реклама в туризме: учебное пособие. 4-е изд., стер. Минск: Новое знание, 2008. 254 с.

2. Карасик В. И. О типах дискурса. Языковая личность: институцииональный и персональный дискурс / В. И. Карасик. Волгоград, 2000. C. 5-20.

3. Карасик В. И. Этнокультурные типы институционального дискурса // Этнокультурная специфика речевой деятельности: Сб. обзоров. М.: ИНИОН РАН, 2000. С. 37-64.

4. Миронова Н. Н. Структура оценочного дискурса: дис. ... д-ра филол. наук: 10.02 .04 и 10.02.19. Москва, 1998. 378 с.

5. Щипицина Л. Ю. К вопросу о комплексной характеристике сетевых СМИ. Журналистика и медиаобразование: сб. трудов III Междун. науч.-практ. конф. (Белгород, 25-27 сентября 2008 г.): в 2 т. Т. 1. / под ред. А. П. Короченского. Белгород: БелГУ, 2008. С. 118-122.

6. Dann G. The Language of Tourism. A Sociolinguistic Perspective. Wallingford: CAB International, 1996. 298 p.

DOI https://doi.org/10.30525/978-9934-26-110-7-71

\section{ВИКОРИСТАННЯ ФЕМІНІТИВІВ ЗА ФАХОМ АБО РОДОМ ЗАНЯТЬ В УКРАЇНСЬКИХ МЕДІАТЕКСТАХ}

\author{
Крапива Ю. В. \\ кандидатка філологічних наук, доцентка, \\ дочентка кафедри загального та прикладного мовознавства \\ Харківський нащіональний університет імені В. Н. Каразіна

\section{Медведь О. В.} \\ кандидатка філологічних наук, дочентка, \\ доцентка кафедри документознавства та украӥнської мови \\ Національний аерокосмічний університет \\ імені М. С. Жуковського «Харківський авіачійний інститут» \\ м. Харків, Украӥна
}

У сучасному світі спостерігаємо зміну соціального статусу жінки, яка намагається реалізувати ті суспільні функції, які їй цікаві. Ідеться про збільшення громадської та професійної активності жінок, що не обмежуються тільки роллю домогосподарки й поступово відвойовують 
позиції в галузях, котрі споконвічно вважалися суто чоловічими (наука, політика, управління тощо).

Зазначені трансформації бачимо і в Україні, де «відбувається процес змін у соціальному просторі, що супроводжується звільненням від радянських смислів» [5, с. 80]. Незважаючи на те що переважна кількість жінок тяжіють до традиційно приписаних ролей, наявна група таких представниць «слабкої статі», які мають яскраво виражені лідерські якості та професійні амбіції.

Оскільки українська мова належить до мов, у яких наявна граматична категорія роду іменників, маємо можливість позначати окремою лексемою особу жіночої статі за фахом або родом занять, як-от: директорка, маркетологиня, деканеса. Саме вони останнім часом $є$ об’єктом бурхливих дискусій як серед мовознавців, так і в широких громадських колах.

Мета нашої наукової розвідки - дослідити поширеність фемінітивів у медіатекстах, ураховуючи загальні зміни екстралінгвістичного плану, а саме закріплення на рівні норми дериваційних засобів для номінації особи жіночої статі за фахом або родом занять, що дозволяє вербалізувати гендер.

Власне термін «фемінітив» позначає іменники жіночого роду, які мають дві групи за значенням. Перша група - іменники, які називають жінок за різними характеристиками: родинними зв'язками, національністю, професією, посадою тощо; друга група фемінітивів - це іменники, які називають самиць тварин [3]. Очевидно, що фемінітиви є усталеною у вживанні й традиційно фіксованою в словниках лексичною групою.

Як справедливо вказує М. Брус, «в українській мові фемінітиви відомі 3 найдавніших дописемних часів, а функціонування їх уреальнило та відобразило книгописання - оригінальне й перекладне» [1]. На думку дослідниці, «упродовж писемної доби поступово зростала кількість фемінітивів від одного синхронного зрізу до іншого», а «регулярне, послідовне творення і тривале використання фемінітивів переросло в тенденцію формування найменувань жінок, співвідносних із назвами чоловіків» [1].

Упровадження фемінітивів за фахом або родом занять у мовленнєву практику активізувалося після нормування в новій редакції українського правопису суфіксів, за допомогою яких можна утворювати такі засоби номінації [4]. Крім того, у серпні 2020 р. Міністерство розвитку економіки, торгівлі та сільського господарства України офіційно дозволило фемінітиви для посад працівниць у кадровій документації. 
Важливу роль у цьому процесі відіграють оновлені та вдосконалені 3МI, адже «через їх критичне сприйняття й осмислення відбувається сучасне формування соціальних структур і суспільної думки, що визначає діяльність членів суспільства, життєві позиції, світоглядні орієнтації, моделі поведінки тощо» [2, с. 37]. За спостереженнями О. Масалітіної, із 2005 р. і до сьогодні вживання фемінітивів збільшилося в 10-11 разів, якщо брати 3МI, публіцистичні тексти [3].

Аналіз вітчизняних інтернет-публікацій за останні три роки свідчить, що в україномовних медіатекстах зростає насамперед кількість номінацій на позначення особи жіночої статі за фахом або родом занять.

При цьому найбільш частотними, за нашими спостереженнями, є фемінітиви, утворені за допомогою суфікса -к-, як-от: «Відставка лідерки соціал-демократів ФРН загрожує коаліції канщлерки Меркель» (DW (укр.), 02.06.2019); «... про це у коментарі УНІАН повідомила речниця МЗС Катерина Зеленко, коментуючи заяву президентки ПАРЕ Ліліан Морі-Паск'є» («Свропейська правда», 04.07.2019); «Прем'єрка Британіі привітала Зеленського $i$ сподівається на співпрацюю» («Свропейська правда», 20.05.2019). Цей суфікс мовознавці вважають найбільш універсальним і продуктивним для утворення назв осіб жіночої статі, зокрема й за фахом чи родом діяльності.

Відзначаючи певну послідовність у використанні фемінітивів на позначення осіб жіночої статі за родом діяльності з суфіксом -к-, не можна, на наш погляд, не помітити й протилежних явищ, які поки що «опираються» вказаній тенденції.

Прикметно, що в останньому наведеному вище прикладі фемінітив використано в заголовку статті, у той час як у самому тексті вжито лексему прем'єр-міністр: «Прем'єр-міністр Великої Британї Тереза Мей привітала з інавгурачією президента Украӥни Володимира Зеленського» («Свропейська правда», 20.05.2019).

Аналогічну ситуацію спостерігаємо й у публікації інтернет-видання «Є Новина!»: «Глядачі звернули увагу на новий стиль депутатки. Народний депутат Надія Савченко з'явилася в прямому ефірі з чокером на ииї» («Є Новина!», 12.06.2019).

Можна припустити, що фемінітиви за родом діяльності поки що зберігають ознаки «аномальності», унаслідок чого автори публікацій за інерцію продовжують використовувати більш традиційні номінації відповідні іменники чоловічого роду.

В україномовних медіатекстах наявні фемінітиви, утворені за допомогою суфікса -ин-, як-от: «Членкиня команди Порошенка Федина заявила...» («Українські новини», 15.06.2019); «Колишня політикиня у 
72 роки заснувала власну кіберкоманду...» («Громадське телебачення», 25.05.2021); «Американська мисткиня украӥнського походження Оля Рондяк: мене надихає моє коріння» («Укрінформ», 26.01.2021). Хоча, за спостереженнями вітчизняних мовознавців, суфікс -ин-зарекомендував себе як продуктивний для утворення назв жінок за сферами наукової діяльності [3], проаналізовані публіцистичні тексти демонструють, на наш погляд, більшу універсальність цього словотворчого афікса.

Спорадично спостережуваними в публіцистичних текстах україномовних інтернет-джерел $є$ назви осіб жіночого роду за фахом чи сферою діяльності з суфіксом -ес-: «У Полтаві відома критикеса презентувала книгу про сучасну украӥнську літературу» («Новини Полтавщини», 18.07.2019); «Вінницька гідеса Тетяна Рибак на 2 місиі в номіначії «Кращий гід на карантині»» («Місто над Бугом», 06.01.2021). Також порівняно нечасто зустрічаються в україномовних текстах вітчизняних електронних видань фемінітиви 3 суфіксом -ищ-: «Мовознавиця про фемінітиви в украӥнській: Час розставить усе на свої місия» (DW (укр.), 04.12.2020).

Цікаво відзначити, що, на противагу внормованим на сьогодні дериваційним моделям, практично не спостерігаємо творення фемінітивів за допомогою суфікса - $\boldsymbol{u}$-, достатньо поширених в українських медіа ще минулого десятиліття: «Мільйонериа з США викреслила синів із заповіту $i$ залишила все багатство собаиі» («Еспресо», 19.01.2015); «"Віце-прем’сриа» 3 гуманітарних питань» («День», № 43, 2003) заголовок статті, у якій іронічно описано життя й побут села Кузьминці. Варто наголосити, що при цьому такі номінації містять у своєму лексичному значенні пейоративні конотації, що, очевидно, і виводить їх 3 активного вжитку в медіатекстах останніх років.

Отже, сучасні україномовні електронні масмедіа активно застосовують дериваційний потенціал української мови для номінації осіб жіночої статі за фахом або родом занять, широко використовуючи спеціалізовані фемінітиви. Позитивний вплив на процес упровадження цих лексем мало закріплення відповідних дериваційних моделей на рівні норми в результаті їхньої легалізації в останній редакції українського правопису. Унаслідок дій на законодавчому рівні відповідні назви осіб за фахом чи родом діяльності вже не маркуються як розмовні одиниці, що, своєю чергою, сприяє вербалізації гендерної рівності. Через високу вагомість електронних 3МI в суспільстві можна прогнозувати поширення фемінітивів у мовленнєвій практиці українців. Перспективним уважаємо подальше спостереження за динамікою використання фемінітивів за фахом чи родом занять в українському медіадискурсі. 


\section{Література:}

1. Давня українська мова. Фемінітиви та їхнє походження. URL: https://www.radiosvoboda.org/a/davnia-ukrayinska-mova/31149104 (дата звернення: 22.06.2021).

2. Литовченко І.В. Особливості сучасних засобів масової інформації як соціального інституту інформаційного суспільства. Вісник НАУ. Серія: Філософія. Культурологія. 2014. № 1 (19). С. 37-40.

3. Маркетологиня, водійка та підприємиця: що таке фемінітиви та чому ми їх вживаємо. URL: https://www.the-village.com.ua/village/city/ talk/285571-marketologinya-vodiyka-ta-pidpriemnitsya-scho-take-feminitivita-chomu-mi-yih-vzhivaemo (дата звернення: 22.06.2021).

4. Український правопис. 2019. URL: https://mon.gov.ua/ua/osvita/ zagalna-serednya-osvita/navchalni-programi/ ukrayinskij-pravopis-2019 (дата звернення: 22.06.2021).

5. Чернявська Л.В. Репрезентація соціального простору в мас-медійному дискурсі. Соиіальні комунікаиії: теорія $і$ практика: наук. журн. / наук. і літ. ред. Г. Я. Холод ; наук. ред. О. М. Холод. Т. 2. К., 2016. C. 79-82. 